УДК 796-057.875:614.8

DOI https://doi.org/10.26661/2663-5925-2021-3-04

\title{
ПОПЕРЕДЖЕННЯ ТРАВМАТИЗМУ ПІД ЧАС ПРАКТИЧНИХ ЗАНЯТЬ СТУДЕНТІВ У ТРЕНАЖЕРНОМУ ЗАЛІ
}

\author{
Конох А. П. \\ доктор педагогічних наук, професор, \\ завідувач кафедри теорії та методики фізичної культури і спорту \\ Запорізький національний університет \\ вул. Жуковського, 66, Запоріжжя, Україна \\ orcid.org/0000-0003-4283-9317 \\ konoch105@ukr.net
}

Баканова О. Ф.

кандидат наук з фізичного виховання і спорту,

дочент кафедри фізичного виховання, спорту та здоров'я

Національний аерокосмічний університет імені М. С. Жуковського «Харківський авіаційний інститут»

вул. Чкалова, 17, Харків, Україна

orcid.org/0000-0002-9642-5198

alextenn@ukr.net

\author{
Конох А. А. \\ кандидат педагогічних наук, \\ доиент кафедри туризму та готельно-ресторанної справи \\ Запорізький національний університет \\ вул. Жуковського, 66, Запоріжжя, Украӥна \\ orcid.org/0000-0001-9719-0418 \\ konoch25@gmail.com
}

Ключові слова:

студенти, попередження

травматизму,

тренажерний зал.
У статті теоретично обгрунтовано профілактичні умови попередження травматизму в процесі практичних занять у закладі вищої освіти. Науковими дослідженнями та практикою фізичного виховання доведено, що систематичне виконання фізичних вправ сприяє зміцненню здоров'я, поліпшенню роботи основних систем організму. Проте виконання рухових дій повинно відбуватися за певними правилами, їх недотримання призводить до різноманітних травм, які негативно впливають на весь організм людини. На практичних заняттях у тренажерному залі студенти отримують значні фізичні навантаження, які відсутні в повсякденному житті. Водночас травматизм має місце в навчальному та тренувальному процесі. Правильно побудовані заняття сприяють попередженню різного роду травм. Отримання травми в процесі фізичного виховання серед студентів були й залишаються серйозною проблемою. Унаслідок травми виникає втрата робочого часу для надання першої допомоги й наступного медичного лікування та реабілітації потерпілого, що збитково для навчально-виховного процесу. Незважаючи на постійні зусилля організаторів фізичного виховання, травматизм на заняттях у тренажерному залі залишається значним, тому проблема травматизму на заняттях з фізичного виховання $\epsilon$ актуальною. Отже, профілактика травматизму - найкращий засіб у боротьбі з травмами. 
У статті аналізуються результати формувального педагогічного експерименту, який показав ефективність упровадження запропонованого спеціального курсу «Попередження травматизму в тренажерному залі» в практичні заняття студентів. Вказується, що в контрольній групі студенти отримали п'ять легких і дві середні травми, а в експериментальній групі травм не зафіксовано, а це свідчить, що, окрім обов'язкового інструктажу 3 техніки безпеки, $\epsilon$ необхідність запровадження додаткових спеціальних заходів з попередження травм у студентів під час занять у тренажерному залі. Доведено, що дотримання установлених норм, правил поведінки попередження травматизму та різного роду ушкоджень, отриманих студентами на заняттях під час практичних занять, дозволяє на належному організаційному рівні провести заняття, зберегти здоров'я, і життя студента.

\title{
PREVENTION OF INJURY DURING PRACTICAL STUDENTS 'CLASSES IN THE GYM
}

\author{
Konoh A. P. \\ Doctor of Pedagogical Sciences, Professor, \\ Head of the Department of Theory and Methods of Physical Culture and Sports \\ Zaporizhzhia National University \\ Zhukovskoho str., 66, Zaporizhzhia, Ukraine \\ orcid.org/0000-0003-4283-9317 \\ konoch105@ukr.net \\ Bakanova O. F. \\ Candidate of Sciences in Physical Education and Sports, \\ Associate Professor at the Department of Physical Fitness, Sports and Health \\ National Aerospace University "Kharkiv Aviation Institute" \\ Chkalova str., 17, Kharkiv, Ukraine \\ orcid.org/0000-0002-9642-5198 \\ alextenn@ukr.net
}

\author{
Konoh A. A. \\ Candidate of Pedagogical Sciences, \\ Associate Professor at the Department of Tourism and Hotel and Restaurant Business \\ Zaporizhzhia National University \\ Zhukovskoho str., 66, Zaporizhzhia, Ukraine \\ orcid.org/0000-0001-9719-0418 \\ konoch25@gmail.com
}

Key words: students, injury prevention, gym.
The article theoretically substantiates the preventive conditions for injury prevention in the process of practical training in higher education establishments. Scientific research and practice of physical education have been proven that the systematic implementation of physical exercises helps to improve health, improve the functioning of the body's major systems. However, the execution of motor actions must follow certain rules, their noncompliance leads to various injuries that adversely affect the entire human body. In the practical classes in the gym, students receive significant physical activity, which is absent in everyday life. At the same time, injuries occur in the educational and training process. Properly constructed classes help to prevent all kinds of injuries. Injury in the process of physical education 
among students has been and remains a serious problem. As a result of the injury, there is a loss of working time for first aid and subsequent medical treatment and rehabilitation of the injured student, which is detrimental to the educational process. Despite the constant efforts of the organizers of physical education, injuries in the gym remain significant. Due to this, the problem of injuries in physical education classes is relevant. Therefore, injury prevention is the best way to deal with injuries. The results of the formative pedagogical experiment are analyzed in the article, which has showed the effectiveness of the proposed special course "Prevention of injuries in the gym" in practical classes of the students. It is indicated that in the control group the students received five slight and two medium injuries, and in the experimental group injuries were not recorded, that indicates that in addition to mandatory safety training it is necessary to use additional special measures to prevent injuries among the students during training time in the gym. It has been proven that compliance with the established norms, rules of behavior to prevent injuries and various injuries received by the students during practical classes, allows at the appropriate organizational level to conduct classes, preserve the health and life of the student.

Постановка проблеми. Одним із найважливіших завдань сучасного суспільства $\epsilon$ розвиток і зміцнення здоров'я дітей та молоді. У процесі фізичного виховання виникає потреба в забезпеченні безпечного середовища під час виконання фізичних вправ. Це зумовило необхідність створення педагогічних умов для профілактики травматизму, забезпечуючи тим самим найкращі умови для фізичного розвитку людини. Оскільки фізичні вправи можуть призводити до травм, на профілактичні заходи під час проведення занять 3 фізичного виховання потрібно звертати увагу насамперед.

Незважаючи на Закон України «Про охорону праці», наказ Державного комітету 3 нагляду за охороною праці від 15.11.2004 року № 255 «Про затвердження Типового положення про службу охорони праці» та рішення колегії Міністерства освіти і науки України від 11 лютого 2010 р., протокол № 1/8-5 «Про стан травматизму під час навчально-виховного процесу серед вихованців, учнів, студентів, працівників і заходи щодо його профілактики», спортивний травматизм у закладах вищої освіти нині розглядається як суттєва проблема соціального плану. Травматизм є однією 3 основних причин, що загрожує життю. Якщо людина травмувалася під час заняття фізичними вправами, то це вже не тільки медична проблема, адже вона спричиняє соціальні наслідки, які негативно позначаються на вихованні, навчанні, на родинних стосунках, працездатності батьків та інших членів сім’і. У травмованих виникає i ще довго зберігається залишковий підвищений рівень тривожності та емоційної неврівноваженості, інколи вони взагалі припиняють займатися фізичними вправами [1].

Проблема виникнення та запобігання травматизму стала предметом дослідження фахівців різ- ного спрямування. Так, різних аспектів цієї проблеми у своїх наукових працях торкалися Р.Г. Алкс, Д.Д. Агарков, Р.Г. В.Ф. Башкіров, З.І. Білоусова, І.А. Бріжата, А.А. Горлов, А.П. Конох, В.І. Майєр, Л.П. Соков, М.К. Хобзей та ін. Проте це були роботи, в яких вивчалась природа дитячого травматизму. Головною ж є проблема створення програм травмопрофілактичної підготовки майбутнього фахівця фізичної культури і спорту, який готовий забезпечити збереження здоров'я своїх дітей та молоді в системі їх фізичного виховання. Натепер рівень травматизму залишається досить високим як у країні загалом, так і в Запорізькій області зокрема, де лише в цьому році внаслідок травм отримали різні ушкодження понад 37 тисяч дітей та молоді [7]. Тенденція до зниження цих показників поки що не спостерігається. На досить високому рівні знаходиться травматизм студентської молоді під час занять фізичними вправами та спортом. Особливо проблематичним сьогодні $є$ травматизм на практичних заняттях у популярному серед студентів тренажерному залі [5]. Отже, актуальність цієї теми у світлі останніх подій не викликає жодних сумнівів.

Мета дослідження - аналіз причин і механізм виникнення травм у студентів під час практичних занять у тренажерному залі.

Виклад основного матеріалу дослідження. Профілактична спрямованість української охорони здоров'я зумовлює проведення комплексу попереджувальних заходів для збереження й зміцнення здоров'я людини. У ці заходи входить величезна за своїми масштабами система iз профілактики травматизму, зокрема в процесі занять у тренажерному залі. Для досягнення мети потрібно правильно організовувати заняття, створювати необхідні умови для забезпечення належного рівня фізичної досконалості. Сприяти 
цьому буде набуття елементарних знань і навичок, які запобігають отриманню травм і важких пошкоджень, погіршенню стану здоров'я. Науковими дослідженнями та практикою фізичного виховання доведено, що систематичне виконання фізичних вправ сприяє зміцненню здоров'я, покращенню роботи основних систем організму. Проте виконання рухових дій повинно проходити за певними правилами $[2 ; 3 ; 4]$. Недотримання цих правил призводить до різноманітних травм, що негативно впливають на весь організм людини. Успішне попередження травм можливе лише в разі знання причин їх виникнення. У науковій літературі є велика кількість робіт, в яких дається аналіз травматизму і причин виникнення травм під час занять фізичною культурою.

Представляється доцільною така класифікація причин виникнення травм: недоліки й помилки в методиці проведення занять; недоліки організації занять і змагань; недоліки в матеріально-технічному забезпеченні занять і змагань; несприятливі метеорологічні та санітарно-гігієнічні умови під час проведення тренувань і змагань; порушення вимог лікарського контролю; недисциплінованість спортсменів.

Травми через недоліки і помилки в методиці проведення занять 3 фізичної культури і спорту становлять більше половини всіх травм і частіше спостерігаються в спортивних іграх, легкій атлетиці, гімнастиці, боротьбі й у силових видах спорту. За недоліків в організації занять і змагань травми в різні роки становлять від 5 до 10\% усіх спортивних травм [8]. Порушення інструкцій i положень щодо проведення тренувальних занять, а також правил безпеки, неправильне складання програм змагань, порушення правил їх проведення нерідко $є$ причиною травм. Вони можуть бути пов'язані з проведенням занять за відсутності тренерів, викладачів, інструкторів або 3 тим, що на кожного $з$ них припадає занадто багато студентів у групі.

3 метою попередження травматизму серед студентів під час практичних занять у тренажерному залі було розроблено і впроваджено спеціальний курс «Попередження травматизму в тренажерному залі». На початку навчального року протягом восьми практичних занять по 10-15 хв., в основній частині кожного заняття у формі бесіди надавалася інформація щодо визначення причин отримання травм під час виконання вправ і шляхи їх запобігання.

Причини травматизму під час занять у тренажерному залі: зневага до обов'язкових трьох видів розминки: розминки загального плану, спеціальної розминки і розминки конкретної області тіла, що тренується; несправність тренувального устаткування; погано спланований процес занять; непідготовлені попередніми заняттями, акцентованими на тренуваннях якої-небудь групи м'язів; неточне виконання вправ, надмірне навантаження; ігнорування страховки під час виконання вправ 3 навантаженнями; відсутність зосередженості під час занять.

Для профілактики травм під час практичних занять рекомендується: уважно стежити за плануванням процесу занять; слідкувати за самостійною роботою студентів; брати активну участь у складанні індивідуальних планів підготовки і коректуванні змісту елективних планів; проводити загальну розминку для розігріву кровоносної системи, м'язів, зв'язок і сухожиль, а потім кісткової системи по напрямку «знизу нагору»; проводити спеціальну розминку по напрямку «зверху вниз» у такому порядку: розминка шиї, кистей рук, ліктьових суглобів і плечового пояса, спини, колінних суглобів і ступень; дотримуватися особливої послідовності у виборі снарядів для пророблення тієї або іншої групи м'язів; під час виконання вправ під час підняття штанги слід використовувати важкоатлетичну методику підйому, коли учень згинає ноги, опускає таз, піднімає голову, дивлячись злегка нагору, тягне штангу до плечей строго вертикально стосовно помосту; для того щоб уникнути травми під час виконання згинання рук зі штангою, слід застосовувати підходи, що розминають, або починати тренування біцепсів 3 гантелями. Виконуючи вправу 3 гантелями, учень може провертати обидві кисті в будь-якому напрямку, вибираючи те положення, де напруга у зв'язок менша. Виконавши кілька підходів такої вправи, можна переходити до більш жорсткого режиму тренування. Цю практику необхідно поширювати і на інші групи м'язів. Основні критерії якості проведеної загальної та спеціальної розминки - легкий піт, рухливість і тепло у всіх групах м'язів; проводити розминку конкретної області, що тренується, а саме розігрів конкретної групи м'язів перед серйозним навантаженням шляхом виконання однієї або двох серій підходів тієї ж вправи $з$ невеликим навантаженням та великим числом повторень від 15-20 і більше [6].

Шляхи усунення помилок у найбільш травмонебезпечних вправах. Небезпечним для хребта $\epsilon$ жим штанги лежачи 3 прогнутою спиною на «мосту». Прагнення перебороти надмірну вагу змушує учня вигинати спину, відриваючи тазову область від лави, та сильно навантажувати за рахунок цього хребет. Такого виконання вправи варто уникати.

Для студентів особливо уразливою є зона плечового поясу. Необхідно уважно підходити до жиму лежачи і підтягувань широким хватом на поперечині. Під час жиму лежачи найбільш частою причиною травм є використання занадто широ- 
кого хвата штанги. Гарантією профілактики травм $€$ страховка. Під час страховки на тренуваннях вправи жим лежачи 3 помірним навантаженням досить одного партнера, який страхує і розташовується за головою атлета так, щоб у разі потреби мати можливість підхопити центральну частину грифа. Під час жиму з граничним навантаженням для страховки необхідні ще два бокових партнери, при цьому головний партнер стоїть позаду учня та стежить за рухом штанги в разі відхилень від вертикалі. Він же керує діями бокових партнерів, якщо учень не в змозі справитися з вагою.

Під час підтягувань на поперечині основною причиною травм плечового поясу $є$ виконання підтягування «ривком-вибухом». Необхідно плавно виконувати рух підтягування, стежачи за технікою виконання вправи - це кращі умови для розвитку сили й об'єму м'язів, упевнена гарантія профілактики травм.

Під час виконання присідань заборонено надмірно нахилятися вперед. Зазвичай нахил уперед буває, коли учень прагне перебороти граничне навантаження без достатньої підготовки. У цьому випадку навантаження на грудино-тазовий відділи хребта сягають у 5-7 разів більше граничного навантаження. Ноги під час присідань атлета повинні бути приблизно на ширині плечей. Більш широке положення ступенів ніг може призвести до травм колінного суглоба та нижньої частини спини, крім того, більш широка стійка не завжди більше надійна. Небажаними є присідання з обмеженою амплітудою, присідання 3 використанням лави для обмеження руху вниз. У нижній фазі вправи юнак різко стикується сідницями $з$ лавою, тому його хребет може бути травмований. Якщо необхідно розвивати силу в потрібних для змагань фазах присіду, то партнери, які страхують юнака, повинні стежити за правильністю виконання фаз вправи. Викладач-тренер повинен пропонувати вправи на тренажері для жиму ногами - у цьому випадку хребет учня витримує значно слабкіші деформуючі навантаження. Після кожного підходу в присіданнях з метою розвантаження хребта доцільно застосовувати вис на поперечині. Страховка під час присідань аналогічна страховці під час виконання жиму лежачи. При цьому основний партнер, який страхує, керує діями бокових партнерів під час постановки снаряда на стійки або підхвату штанги за кінці грифа в разі невдалої спроби юнака встати з підсіду, завалювання снаряда вперед або назад, перекосу грифа.

Під час виконання майже всіх вправ силового характеру варто пам'ятати про утримання найближче до тіла снаряда, 3 яким учень виконує вправи.

Такі вправи, як тяга в нахилі до поясу, тяга стоячи до підборіддя, випрямлення рук униз 3 використанням блокового пристрою в тренуванні трицепсів, можуть виявитися небезпечними для хребта, якщо рух кінцівок не буде відбуватися поруч із тілом. Якщо ж була отримана травма, що відобразилася в забитому місці, розтяганні, необхідно зробити холодний компрес на зону травмованого м'яза або суглоба. Після цього треба негайно припинити тренування i звернутися до лікаря, який поставить точний діагноз. Не відновлювати заняття 3 обтяженнями до повного відновлення. Неправильне відновлення, навіть після розтягання сухожилля, може у випадку поспішного поновлення тренувань стати провокуючим моментом для більш серйозної травми. Після травми необхідно утримуватися від тренувань на весь термін, запропонований травматологом. У цьому гарантія нормального ходу лікування i відновлення, що повинне йти дуже поступово й обережно. У разі поновлення тренувань слід вибирати такі вправи, щоб трохи по-іншому проробляли м'язи в порівнянні із вправою, під час якої була отримана травма. Рекомендується певний час попрацювати 3 помірними навантаженнями i більшим числом повторень, щоб підвищити приплив крові до м’язів, що тренуються. Така технологія сприяє найшвидшому відновленню. Щоб тренування з обтяженнями не завдали шкоди здоров'ю, не призвели до травм, треба правильно виконувати розминки, бути зосередженим та акуратним під час виконання вправ. Ніколи не забувати про якісну страховку у вправах, спрямованих на розвиток силових якостей. Для профілактики травм під час занять студентів силовим фітнесом рекомендуються: правильне технічне виконання вправ; забезпечення страховки; якісна розминка; під час тренувань юнакам варто давати вправи на розвантаження; перед кожним тренувальним заняттям і після нього рекомендується виконувати ряд вправ 3 напруженням і розслабленням м'язів і зв'язок, виси $з$ розгойдуванням на шведській стінці, оберти у великих суглобах; після тренування необхідно відпочивати лежачи 3 підкладеним під ділянку попереку валиком; для профілактики травм спини рекомендується надягати широкий шкіряний пояс, а для попередження гриж - бандаж; щоб уникнути розтягання зв' язок променево-зап'ястного суглоба під час тренувань і змагань, юнак повинен надягати шкіряні напульсники чи бинтувати променево-зап'ястні суглоби еластичним бинтом; ретельна перевірка закріплення ваги на штанзі перед виконанням жима лежачи, тяги, присідання; перед кожним підходом до штанги зобов'язані використовувати магнезію, попередньо знежирюючи руки; безпосередньо перед змаганням, а також у період підготовки до нього, юнак повинен проводити енергійну, ретельну розминку, після якої присту- 
пити до тренування 3 невеликим навантаженням, поступово підвищуючи його до максимального; взуття повинне мати твердий закаблук і широкий підбор висотою 1-1,5 см, а задля профілактики розвитку плоскостопості можна рекомендувати на час тренувань і змагань вкладати у взуття супінатори; для уникнення травм долонь поверхня штанги повинна бути гладкою, без іржі; для попередження утворення на долонях мозолів, а також їх розривів і можливих гнійних ускладнень, той, що займається, повинен ретельно доглядати за шкірою; для профілактики перелому грудини окремі тренери рекомендують «вкладати» гриф штанги більше на плечі, ніж на груди. Однак не для всіх така вправа часом нездійсненна, i вони у свою чергу рекомендують вкладати штангу на груди в момент вдиху, тобто на так званий повітряний амортизатор.

Впроваджений спеціальний курс «Попередження травматизму в тренажерному залі» в прак- тичні заняття студентів зробив можливим протягом навчального року уникнути травматичного ушкодження студентів. У контрольній групі студенти отримали п'ять легких і дві середні травми, а в експериментальній групі травм не зафіксовано, а це свідчить, що, окрім обов'язкового інструктажу 3 техніки безпеки, $є$ необхідність запровадження додаткових спеціальних заходів попередження травм у студентів під час практичних занять у тренажерному залі.

Висновки. Отримані дані переконливо свідчать про високу ефективність запропонованого спеціального курсу «Попередження травматизму в тренажерному залі» в практичні заняття студентів та необхідність ії впровадження у фізичне виховання закладів вищої освіти.

Перспективи подальших розвідок у цьому напрямі полягають у визначенні стану травматизму під час проведення занять фізичними вправами і спортом різних груп населення.

\section{ЛІТЕРАТУРА}

1. Бойченко Ю. Профілактика травматизму на уроках фізичної культури і перша долікарська допомога. Фізичне виховання в школі. 2009. № 4. С. 21-24.

2. Бріжата І.А. Впровадження технологій травмопрофілактики школярів у підготовці майбутніх учителів фізичної культури. Освіта і здоров'я: формування здоров'я дітей, підлітків та молоді в умовах навчального закладу. Суми : СумДПУ ім. А.С. Макаренка, 2008. С. 36-40.

3. Велитченко В.К. Физкультура без травм. Москва : «Просвещение», 1993. С. 5-6.

4. Мардар Г. Запобігання травматизму в процесі підготовки спортсменів. Фізичне виховання, сnорт $i$ культура здоров'я у сучасному суспільстві : зб. наук. праць. Луцьк : РВВ «Вежа», 2008. С. 82-87.

5. Мужичок В.О. Профілактика та попередження травматизму в фізкультурній та спортивній діяльності студентів ВНЗ. Молодий вчений. 2017. № 3.1 (43.1). С. 257-261.

6. Оленєв Д.Г., Діденко С.А. Методичні рекомендації для науково-педагогічних працівників і студентів усіх спеціальностей університету «Правила безпеки та профілактика травматизму студентів на заняттях з фізичного виховання та спорту». Київ : ДУТ, 2014. 50 с.

7. Показники травматолого-ортопедичної допомоги населенню України 2009-2010. Київ, 2011. 120 с.

8. Техніка безпеки на уроках фізкультури. URL: http://ukrefs.com.ua/page,8,103092-Tehnikabezopasnosti-na-urokahfizkul-tury.html (accessed: 20.09.2021).

\section{REFERENCES}

1. Boichenko Y. (2009). Profilaktyka travmatyzmu na urokakh fizychnoyi kul'tury i persha dolikars'ka dopomoha [Injury prevention in physical education classes and first aid]. Physical education at school. 2009. № 4. S. 21-24.

2. Brizhata I.A. (2008). Vprovadzhennya tekhnolohiy travmoprofilaktyky shkolyariv u pidhotovtsi maybutnikh uchyteliv fizychnoyi kul'tury [Introduction of trauma prevention technologies for schoolchildren in the training of future physical education teachers]. Education and health: shaping the health of children, adolescents and young people in an educational institution. Sumy: Sumy State Pedagogical University named after A.S. Makarenko, 2008. S. 36-40.

3. Velytchenko V. K. (1993). Fizkul'tura bez travm [Physical education without injuries]. Moscow: Enlightenment. (in Russian)

4. Mardar G. (2008). [Injury prevention in the process of training athletes]. Physical education, sports and health culture in modern society. Lutsk: RVV Tower. C. 82-87.

5. Muzhycok V.O. (2017). Profilaktyka ta poperedzhennya travmatyzmu v fizkul'turniy ta sportyvniy diyal'nosti studentiv VNZ [Prevention and prevention of injuries in physical culture and sports activities of university students]. A young scientist. № 3 (43.1). 2017. S. 257-261.

6. Oleniev D.G., Didenko S.A. (2014). Pravyla bezpeky ta profilaktyka travmatyzmu studentiv na zanyattyakh z fizychnoho vykhovannya ta sportu [Safety rules and prevention of injuries of students in physical 
education and sports]. Methodical recommendations for scientific and pedagogical workers and students of all specialties of the university. Kyiv: DUT. (in Ukrainian)

7. Pokaznyky travmatoloho-ortopedychnoyi dopomohy naselennyu Ukrayiny 2009-2010 [Indicators of
[ trauma and orthopedic care for the population of Ukraine 2009-2010]. (2011). Kyiv. (in Ukrainian)

8. Tekhnika bezpeky na urokakh fizkul'tury [Safety in physical education classes]. Retrieved from: http://ukrefs.com.ua/page, 8,103092-Tehnika-bezopasnosti-na-urokahfizkul-tury.html

(accessed (20.09.2021)). 